\title{
Knowledge, attitude and perceptions about Crimean Congo Haemorrhagic Fever (CCHF) among occupationally high-risk healthcare professionals of Pakistan
}

\author{
Ali Ahmed ${ }^{1,2^{*}}$ (D) Muhammad Saqlain², Maria Tanveer ${ }^{2}$, Azhar Hussain Tahir², Fakhar Ud-Din², \\ Maryum Ibrar Shinwari ${ }^{3}$, Gul Majid Khan ${ }^{2}$ and Naveed Anwer ${ }^{2}$
}

\begin{abstract}
Background: Crimean Congo Haemorrhagic Fever (CCHF), a tropically neglected infectious disease caused by Nairovirus, is endemic in low middle-income countries like Pakistan. Emergency health care professionals (HCPs) are at risk of contracting nosocomial transmission of CCHF. We, therefore, aim to analyze the knowledge, attitudes, and perceptions (KAP) of at-risk physicians, nurses, and pharmacists in Pakistan and the factors associated with good KAP.

Method: A validated questionnaire (Cronbach's alpha 0.71) was used to collect data from HCPs in two CCHF endemic metropolitan cities of Pakistan by employing a cross-sectional study design. For data analysis percentages, chi-square test and Spearman correlation were applied by using SPSS version 22.

Results: Of the 478 participants, 56\% $(n=268)$ were physicians, 37.4\% $(n=179)$ were nurses, and $6.5 \%(n=31)$ were pharmacists. The proportion of HCPs with good knowledge, attitude, and perception scores was $54.3 \%$, 81 , and $69 \%$, respectively. Being a physician, having more work experience, having a higher age, working in tertiary care settings, were key factors for higher knowledge $(p<0.001)$. The correlation coefficient showed significant positive correlation between attitude- perception $(r=0.560, p<0.001)$.

Conclusion: We have observed average knowledge of HCPs. Therefore, we recommend time to time education campaigns and workshops in highly endemic CCHF regions to be launched by health ministries and HCPs, in particular nurses, encouraged to follow authentic academic sources of information to prevent nosocomial transmission.
\end{abstract}

Keywords: CCHF, Eid-ul-Adha, Healthcare workers, High risk, Zoonotic, Pakistan

\footnotetext{
* Correspondence: ali.ahmed@monash.edu

'School of Pharmacy, Monash University, Jalan Lagoon Selatan, Bandar

Sunway, 47500 Subang Jaya, Selangor, Malaysia

2Department of Pharmacy, Quaid-i-Azam University, Islamabad 45320,

Pakistan

Full list of author information is available at the end of the article
}

(c) The Author(s). 2021 Open Access This article is licensed under a Creative Commons Attribution 4.0 International License, which permits use, sharing, adaptation, distribution and reproduction in any medium or format, as long as you give appropriate credit to the original author(s) and the source, provide a link to the Creative Commons licence, and indicate if changes were made. The images or other third party material in this article are included in the article's Creative Commons licence, unless indicated otherwise in a credit line to the material. If material is not included in the article's Creative Commons licence and your intended use is not permitted by statutory regulation or exceeds the permitted use, you will need to obtain permission directly from the copyright holder. To view a copy of this licence, visit http://creativecommons.org/licenses/by/4.0/ The Creative Commons Public Domain Dedication waiver (http://creativecommons.org/publicdomain/zero/1.0/) applies to the data made available in this article, unless otherwise stated in a credit line to the data. 


\section{Background}

Crimean Congo Haemorrhagic Fever (CCHF) or viral hemorrhagic fever is a zoonotic disease spread by $\mathrm{Hya}$ lomma tick bites or by contact with infected animals [1, 2]. The pleomorphic RNA virus causes CCHF belonged to the family Nairoviridae the genus Orthonairovirus [3]. This lethal virus is seroprevalent in the Middle East, Central African, and Asian countries such as India and Pakistan [4]. CCHF outbreaks pose a threat to public health systems due to its long-term and severe mechanism of infection, its propensity for epidemics, its high case-fatality rate $(10-40 \%)$ and its capacity for nosocomial outbreaks, and its diagnosis and preventive difficulties [5-7].

CCHF virus transmission occurs mainly through the crushing of carrier ticks by bare hands, contact with infected blood or tissues of infected animals during or after slaughter, human to human transmission may also occur through contact with body fluids, blood or organs of the infected person [7-9]. Nosocomial infection may also result from contact with contaminated medicalsurgical equipment, improper sterilization and re-use of the injection needles $[6,7,10]$. During Eid ul Adha, the largest Muslim religious festival in which millions of animals are slaughtered, the rate of new infections increase several times [11-13]. Farmers, dairy workers, slaughterhouse workers, veterinarians, and Health Care Professionals (HCPs) in endemic regions are at high risk of contracting CCHF [7, 10, 13].

Crimean Congo Hemorrhagic Fever Virus (CCHFV) continues to increase in Pakistan between January 2014 and May 2020, with around 356 CCHF patients confirmed across the country by the National Institute of Health, Islamabad, Pakistan, with a $25 \%$ mortality rate [14-16]. Of these patients, 38\% were reported from Balochistan, followed by $23 \%$ from Punjab, 19\% from Khyber Pakhtunkhwa, 14\% from Sindh, and 6\% from Islamabad $[14,16]$. Zohaib et al. reported $2.7 \%$ of CCHF seroprevalence in Pakistan with increased prevalence in rural residents, possibly due to increased exposure to animals [17]. High risk of nosocomial transmission of CCHFV was reported for the first time in 1976 when laparotomy of a CCHF patient was performed in Pakistan, resulting in 11 secondary cases of hospital transmission leading to 3 deaths $[10,18]$. Recently, due to the highly contagious nature of $\mathrm{CCHF}$ and not following serious precautionary measures, multiple nosocomial transmissions and deaths of HCPs have occurred in different regions of Pakistan, such as in Quetta, Abbottabad, Rawalpindi, and Bahawalpur [19-21]. HCPs should know with what signs CCHF patients will visit hospitals and be aware of the potential for imports of CCHF from endemic regions, human to human nosocomial transmission [10, 22]. Early suspicion and diagnosis are needed to take immediate and strict precautions to prevent transmission in the community and the hospital [23]. All HCPs that may be involved in CCHF case management should receive adequate education regarding disease [24].

Knowledge, Attitude, and Perception (KAP) studies provide information on existing programs, and their results help develop future effective behavioral strategies [25]. Some studies have reported KAP of students and HCPs about CCHF in Pakistan, Iran, and Turkey [10, 23, 26-28]. However, due to the limited evidence available, we aim to conduct knowledge, attitude, and perceptions assessment study among occupationally at-risk HCPs in the endemic region of Pakistan. The findings of the study will be essential to highlight the significant gaps in the literature on HCPs awareness of CCHF, which, in turn, will help in the design of appropriate interventions to prevent future nosocomial transmission.

\section{Methods \\ Ethical approval}

The study was performed in accordance with the declaration of Helsinki. Ethical approval was first obtained from the Department of Pharmacy, Quaid I Azam University, Islamabad (Letter No: QAU/PharmacyDept/214), and the other ethical permission was obtained from the Ethical Review Board of Shaheed Zulfiqar Ali Bhutto Medical University (Letter No: F.1-1/2016/ERB/ SZABMU/08/16).

\section{Study design and settings}

The multicenter, institutional-based, cross-sectional study was conducted in Islamabad and Rawalpindi, the two metropolitan cities of Pakistan. We choose these cities because previously, nosocomial transmissions of CCHF have been reported from these areas [18, 29, 30]. Islamabad and Rawalpindi are in the Potohar region of northern Punjab. The data was collected from five tertiary care government hospitals (Pakistan Institute of Medical Sciences, Islamabad; Polyclinic Hospital, Islamabad; Benazir Bhutto Hospital, Rawalpindi; Holy Family Hospital, Rawalpindi; District Health Quarter, Civil Hospital, Rawalpindi) and two private secondary care hospitals (Maroof International Hospital, Islamabad \& Ali Medical Complex, Islamabad). The STROBE (Strengthening the reporting of observational studies in epidemiology) checklist was used to report the current analysis.

\section{Sample size, participants and procedure}

The sample size calculated by Raosoft calculator was 377 by assuming $95 \% \mathrm{CI}, 5 \%$ margin of error, $\mathrm{Z}$ of 1.96 , and considering the 20,000 population [31]. To get more reliable results, we approached 563 HCPs. A convenient 
sampling technique was used to collect data from medical institutions. We targeted emergencies and infectious disease departments of the selected hospitals to enroll only those HCPs who have significant chances of exposure to CCHF. The study population included only mainstream HCPs such as physicians, pharmacists, and nurses working in hospitals. All HCPs working in other hospital departments such as dentistry, psychiatry, neurology, obstetrics, gynaecology, haematology, blood bank, endocrinology, nephrology, hepatology, and cardiology were excluded from the study. Students, laboratory staff, and administrative staff were also excluded from the study. The study was carried out from August 2018 to January 2019. Out of 563 questionnaires that were distributed in consented participants, 501 (88.9\%) questionnaires were returned. The data was collected during working hours, and questionnaires were distributed and collected by the trained principal investigators.

\section{Study questionnaire}

The study instrument was designed based on the thorough literature review and information retrieved from the official webpage of the World Health Organization (WHO) regarding CCHF transmission, precautions, epidemiology, seasonal impact, clinical management, and previous studies [23, 27, 32, 33]. The questionnaire was validated in two steps in the first step initial version was sent to researchers from academia, medical professionals (Physicians, Nurses, and Pharmacists) for their suggestions regarding appropriateness, conciseness, and importance. After amendments, in second phase instrument was pilot tested on conveniently available 45 HCPs, including the equal number of pharmacists, doctors, and nurses for cognitive debriefing. Participants were requested to provide feedback on any issues relating to the understanding of the questionnaire. Two questions were modified based on the comments of the participant. The reliability of the instrument was checked by SPSS Version 26, overall Cronbach's alpha was reported to be 0.71 , and the participants of the pilot study were not included in the final analysis.

The final version of the tool consisted of four parts for the assessment of demographics, knowledge, attitudes, and perceptions. The demographic section was comprised of gender, age, profession, experience, city of practice, and one item about the major source of information regarding CCHF. The knowledge section included 24 questions and assessed by giving a score of 1 to correct answer and 0 to the wrong answer. Items were evaluated in multiple-choice questions. If HCPs correctly answer 14 questions, he/she regarded as having good knowledge.

The attitude section had six questions, and each item was recorded on a 5-point Likert scale (1 strongly disagree, 2 disagree, 3 neutral, 4 agree, 5 strongly agree). Likewise, the perception portion had 7 questions, and each was assessed on 5 points Likert scale ( 1 strongly disagree, 2 disagree, 3 neutral, 4 agree, 5 strongly agree).

\section{Statistical analysis}

The statistical analysis was performed by SPSS version 26. Frequencies and percentages have been calculated for categorical variables. Chi-square tests were used to investigate the statistically significant association between the demographic characteristics of the respondent and the KAP items. $p<0.05$ was considered statistically significant. Spearman correlation tests were also performed to find a statistically significant correlation between knowledge, attitude, and perception scores.

\section{Results}

A total of 478 participants were included in the final analysis after the removal of questionnaires containing missing information $(n=23)$. Table 1 shows demographics of the study population as $68.4 \%$ were female; $56.1 \%$ were physicians; $36 \%$ were $26-33$ years of age; $58 \%$ were married, and $81.4 \%$ were working in tertiary care settings. For CCHF-related information, 20\% of HCPs prefer research articles, $40 \%$ chose social media sites (Facebook, Twitter, YouTube, and Television), 20\% seek workshops/conferences and 20\% like to read brochures and newsletters.

The study found that 54.3\% $(n=260)$ of HCPs had good knowledge. $82 \%(n=392)$ respondents correctly answered that contact with infected Hyalomma ticks leads to the Transmission of CCHF, $n=350$ (73.2\%) HCPs correctly identified the causative agent of CCHF. $54 \%(\mathrm{n}=260)$ were aware of the best prophylactic measures against CCHF. 64\% $(n=306)$ familiar with the symptoms of CCHF viral disease. $58 \%(n=282)$ were mindful of standard treatment options available for CCHF. $47.2 \%(n=226)$ were aware of the route of administration of anti-CCHF drug Ribavirin. 42.5\% $(n=$ 203) reported Balochistan is the most affected province of Pakistan. Findings revealed that knowledge status was significantly differed by age, gender, marital status, experience, and practice category $(p<0.001)$. Results demonstrated that physicians have the highest knowledge score (67.5\%) followed by pharmacists (64.5\%) and nurses $(40 \%)$. While knowledge status was not significantly differed by region $(p=0.005)$ (Tables 2 and 3).

Regarding attitudes, about half $(48.54 \%, \& 49.37 \%)$ of respondents were agreed that early diagnosis had a positive effect on CCHF treatment, and supportive care can be helpful for CCHF, respectively. The responses were significantly $(p<0.005)$ varied by age, profession, and experience. Similarly, 46.65\% HCPs assumed that they are at risk of getting the infection, and $48.74 \%$ felt fear in 
Table 1 Demographics of the study population

\begin{tabular}{|c|c|}
\hline & n (\%) \\
\hline \multicolumn{2}{|l|}{ Gender } \\
\hline Female & $327(68.4)$ \\
\hline Male & 151 (31.6) \\
\hline \multicolumn{2}{|l|}{ Profession } \\
\hline Physician & $268(56.1)$ \\
\hline Nurses & $179(37.4)$ \\
\hline Pharmacist & $31(6.5)$ \\
\hline \multicolumn{2}{|l|}{ Age } \\
\hline $18-25$ & $142(30)$ \\
\hline $26-33$ & $172(36)$ \\
\hline $34-41$ & $83(17.4)$ \\
\hline $42-49$ & $51(10.7)$ \\
\hline 50 and above & $30(6.3)$ \\
\hline \multicolumn{2}{|l|}{ Marital Status } \\
\hline Yes & $279(58.4)$ \\
\hline No & 199 (41.6) \\
\hline \multicolumn{2}{|c|}{ Experience (Years) } \\
\hline $0-3$ & $200(41.8)$ \\
\hline $4-6$ & $138(28.9)$ \\
\hline $7-9$ & $83(17.4)$ \\
\hline 10 and above & $57(11.9)$ \\
\hline \multicolumn{2}{|l|}{ City of Practice } \\
\hline Rawalpindi & $211(44.2)$ \\
\hline Islamabad & $267(55.8)$ \\
\hline \multicolumn{2}{|c|}{ Category of Practice } \\
\hline Secondary & 89 (18.6) \\
\hline Tertiary & 389 (81.4) \\
\hline
\end{tabular}

dealing with $\mathrm{CCHF}$ patients. The responses were significantly differed by experience, profession, age, category of practice $(p<0.005)$ (Table 4$)$.

$56 \%$ HCPs agreed that following standard procedures will minimize the risk of Transmission. The response was significantly differed by profession $(p=0.001) .48$ and $51 \%$ HCPs agreed that those people who have pets at home and animal handlers are at increased risk of contracting the CCHFV. The responses varied significantly in terms of age, marital status, and practice experience $(p<0.05) .58 \%$ of healthcare professionals agreed that they were well equipped with the necessary quarantine observation skills. The response was significantly varied by profession $(p<0.001)$, marital status $(p<0.001)$, and experience $(p=0.01)$ (Table 5).

Spearman correlation tests revealed that there is a strong linear positive correlation between attitudeperception $(\mathrm{r}=0.560, p<0.001)$. However, there is a weak positive correlation between knowledge-attitude $(\mathrm{r}=0.092, p=0.045)$.

\section{Discussion}

To effectively treat CCHF patients without risk of nosocomial infection, HCPs need to have good knowledge, attitude, and practices of preventive measures, such as before visiting a patient, wearing gloves, masks, protective clothing, goggles, disposable clothing and face shields [33]. Very little was found in the literature on the question of emergency HCPs' knowledge attitude and perceptions, so this is the first study in the CCHF endemic region of Pakistan where previously frequent nosocomial transmissions have been reported [12, 18, 29, 34].

Our study reported $54.3 \% \mathrm{HCPs}$ to have good knowledge while Rahnavardi et al. reported $50.34 \%$ of participants had good knowledge [23]. A possible explanation of higher knowledge in our study might be that Iranian research has included a smaller number of physicians and nurses while included more paramedics, laboratory personals, and orderlies [23]. However, in the case of senior physicians, Iran and the Turkish study reported a higher proportion of 90.20 and $84.27 \%$ than our $83 \%[23,35]$. Our study reported better knowledge then the survey conducted among medical and pharmacy students in Pakistan [27]. One possible explanation might be that students are more focused on their current subjects for examination, while HCPs in our study deal directly with patients so that they are better prepared.

Of note that, according to an Iranian study when the question was asked; CCHF can be transmitted through percutaneous contact from an infected individual, 89.5\% participants provided correct answer while in our study $71 \%$ study participants provided correct answers similarly in Turkish study $98.2 \%$ physicians correctly answer this question $[23,36]$. This finding is of particular interest as the percutaneous route of nosocomial Transmission has been identified as a potential route for $\mathrm{CCHF}$ transmission in the past nosocomial outbreak of CCHF in Rawalpindi, Pakistan [18]. In our study, only 21 and $42 \%$ of HCPs were aware of the most affected months, and the most affected province of Pakistan from CCHF, a considerable lack of epidemiological knowledge, was observed. Since the disease is endemic in Pakistan and the study area is at risk of illness due to the regular and more frequent transport of livestock during the Eid ul Adha season [12], it is vital to train health workers and to distribute brochures and posters containing CCHFrelated information to all health clinics and health centres.

In 2000, Sheik et al. indicated that there was a lack of knowledge of HCPs regarding prevention and burial 
Table 2 Knowledge of HCPs towards CCHF

\begin{tabular}{|c|c|c|c|}
\hline Serial No. & Question & Correct n (\%) & Incorrect $\mathbf{n}(\%)$ \\
\hline 1 & CCHF is caused by? & $398(83.21)$ & $80(16.80)$ \\
\hline 2 & The predominant symptoms associated with CCHF are: & $306(64.01)$ & $172(35.98)$ \\
\hline 3 & CCHF can be transmitted through percutaneous contact? & $340(71.12)$ & $138(28.87)$ \\
\hline 4 & The spread of CCHF occurs through & $281(58.78)$ & $197(41.21)$ \\
\hline 5 & Contact with an infected vector can be a mode of transmission to human & $392(82.00)$ & $86(17.99)$ \\
\hline 6 & Contact with human blood and body fluids can also be transmission source & $63(13.17)$ & $415(86.82)$ \\
\hline 7 & Contact with animals cannot transfer CCHF & $225(47.07)$ & $253(52.92)$ \\
\hline 8 & Most affected province of Pakistan? & $203(42.46)$ & $275(57.53)$ \\
\hline 9 & Most affected months of the year? & 99 (20.71) & $379(79.28)$ \\
\hline 10 & The most common cause of hospital born Congo Infection? & $343(71.75)$ & $135(28.24)$ \\
\hline 11 & CCHF is highly symptomatic in infected animals: & $160(33.47)$ & $318(66.52)$ \\
\hline 12 & The mortality rate of CCHF in Pakistan? & $242(50.62)$ & $236(49.37)$ \\
\hline 13 & What diagnostic options are available for CCHF? & $259(54.18)$ & $219(45.81)$ \\
\hline 14 & Is the standard treatment option available for CCHF? & $282(58.99)$ & $196(41.00)$ \\
\hline 15 & Best prophylactic measures against CCHF? & $260(54.39)$ & $218(45.60)$ \\
\hline 16 & Is CCHF a zoonotic disease? & $339(70.92)$ & $139(29.07)$ \\
\hline 17 & Is there any vaccine available for CCHF? & $222(46.44)$ & $256(53.55)$ \\
\hline 18 & Can CCHF be transmitted via air and water? & $179(37.44)$ & $299(62.55)$ \\
\hline 19 & Can CCHF be transferred through social contacts & $270(56.48)$ & $208(43.51)$ \\
\hline 20 & Can CCHF be cured entirely with medicine? & $327(68.41)$ & $151(31.58)$ \\
\hline 21 & Contact with feces, urine, and saliva of an infected person can cause CCHF? & $309(64.64)$ & $169(35.35)$ \\
\hline 22 & Does avoiding mosquitoes bites prevents CCHF? & $181(37.86)$ & $297(62.13)$ \\
\hline 23 & Is Ribavirin taken as orally? & $226(47.28)$ & $252(52.71)$ \\
\hline 24 & The loading dose of Ribavirin taken for CCHF is: & $125(26.00)$ & $402(84.10)$ \\
\hline
\end{tabular}

procedures for CCHF patients [26]. Our results have shown a significant association between higher education, experience, and higher knowledge, a finding that is consistent with that of Turkish and Iranian studies [23, $35,36]$. Those working in tertiary care settings have more knowledge than those working in secondary care settings, possibly due to more facilities, workshops, and patient flow, and these results are consistent with the study conducted in India [37].

In Pakistan, nurses are at the highest risk because they are the first HCPs to interact with patients for passing the Intravenous line and taking blood samples for testing, and there is a chance of accidental needle stick injury that could result in nosocomial Transmission [38]. Educational training should be provided to nurses to educate them about protective measures and, if they have received such injury, what they should do immediately as they should know about the dose of Ribavirin (antiviral) to be used as prophylaxis.

Since emergency HCPs frequently encounter CCHF patients and have a high chance of percutaneous infection, $46 \%$ of HCPs in our study believe that Pakistan's health will not be able to cope appropriately if such an incident occurs in the same way as Haq et al. reported the incompetence of Pakistan's healthcare system in dealing with health emergencies [39]. The majority of study subjects agreed that animal herders and having pets increased risk of CCHF infection, just like Georgian and Turkish studies [8, 40, 41].

Despite the positive attitudes and perceptions of HCPs towards CCHF, knowledge of HCPs about CCHF was poor. Possible explanations may be due to a busy schedule and additional workload, as well as a lack of regular education programs. HCPs continuing education in $\mathrm{CCHF}$ should be used to raise awareness of $\mathrm{CCHF}$ preventive methods, treatment options, identification of ineffective diagnostic factors, the role of hyalomma ticks in Transmission, disease epidemiology, most affected months of the year, and any specific event that may result in CCHF transmission, such as Eid ul Adha. Senior physicians, despite having higher knowledge, could not motivate junior physicians, nurses, pharmacists to improve their knowledge and practice. Despite their 
Table 3 Association of knowledge with demographics

\begin{tabular}{|c|c|c|c|}
\hline & Good Knowledge n (\%) & Poor Knowledge $n$ (\%) & $P$-Value \\
\hline Total & $260(54.39)$ & $218(45.61)$ & \\
\hline \multicolumn{4}{|l|}{ Gender } \\
\hline Female & $184(56.2)$ & $143(43.8)$ & \\
\hline Male & $76(50.3)$ & $75(49.7)$ & \\
\hline Profession & & & $<0.001$ \\
\hline Physicians & $181(67.5)$ & $87(32.5)$ & \\
\hline Nurses & $71(40)$ & $108(60)$ & \\
\hline Pharmacists & $20(64.5)$ & $11(35.5)$ & \\
\hline Age & & & $<0.001$ \\
\hline $18-25$ & $60(42.3)$ & $82(57.7)$ & \\
\hline $26-33$ & $89(51.7)$ & $83(48.3)$ & \\
\hline $31-38$ & $57(68.7)$ & $26(31.3)$ & \\
\hline $39-46$ & $39(76.5)$ & $12(23.5)$ & \\
\hline 47 and above & $25(83.3)$ & $5(16.7)$ & \\
\hline Marital status & & & $<0.001$ \\
\hline Married & $151(54.1)$ & $128(45.9)$ & \\
\hline Single & $106(55.5)$ & $85(44.5)$ & \\
\hline Experience of practice & & & $<0.001$ \\
\hline $0-3$ & $80(47)$ & $90(53)$ & \\
\hline $4-6$ & $73(52.9)$ & $65(47.1)$ & \\
\hline $7-9$ & $64(62)$ & $39(38)$ & \\
\hline$>10$ & $56(83.5)$ & $11(16.5)$ & \\
\hline Region & & & 0.055 \\
\hline Rawalpindi & $112(53)$ & $99(47)$ & \\
\hline Islamabad & $146(54.7)$ & $121(45.3)$ & \\
\hline Category of practice & & & $<0.001$ \\
\hline Secondary & $40(44.9)$ & $49(55.1)$ & \\
\hline Tertiary & $246(63.2)$ & $143(36.8)$ & \\
\hline
\end{tabular}

Significant $p$ value $<0.05$

Table 4 Attitude of HCPs towards CCHF and differences in responses by demographic characteristics

\begin{tabular}{|c|c|c|c|c|c|c|c|c|c|c|c|c|}
\hline Attitude assessing questions & SD & D & $\mathrm{N}$ & A & SA & Gender & Profession & Age & $\begin{array}{l}\text { Marital } \\
\text { status }\end{array}$ & $\begin{array}{l}\text { Experience } \\
\text { of Practice }\end{array}$ & Region & $\begin{array}{l}\text { Category } \\
\text { of practice }\end{array}$ \\
\hline $\begin{array}{l}\text { Effect of early diagnosis } \\
\text { on CCHF }\end{array}$ & $\begin{array}{l}30 \\
(6.28)\end{array}$ & $35(7.32)$ & $\begin{array}{l}64 \\
(13.39)\end{array}$ & $\begin{array}{l}232 \\
(48.54)\end{array}$ & $\begin{array}{l}117 \\
(24.48)\end{array}$ & .692 & $<0.001$ & $<0.001$ & .009 & .007 & $<0.001$ & $<0.001$ \\
\hline $\begin{array}{l}\text { Is supportive care helpful } \\
\text { for CCHF }\end{array}$ & $\begin{array}{l}15 \\
(3.14)\end{array}$ & $38(7.95)$ & $\begin{array}{l}83 \\
(17.36)\end{array}$ & $\begin{array}{l}236 \\
(49.37)\end{array}$ & $\begin{array}{l}106 \\
(22.18)\end{array}$ & .494 & .004 & .015 & $<0.001$ & .006 & $<0.001$ & $<0.001$ \\
\hline $\begin{array}{l}\text { Are you at risk of } \\
\text { contracting CCHF? }\end{array}$ & $\begin{array}{l}14 \\
(2.93)\end{array}$ & $\begin{array}{l}48 \\
(10.04)\end{array}$ & $\begin{array}{l}71 \\
(14.85)\end{array}$ & $\begin{array}{l}223 \\
(46.65)\end{array}$ & $\begin{array}{l}122 \\
(25.52)\end{array}$ & .282 & $<0.001$ & $<0.001$ & $<0.001$ & $<0.001$ & $<0.001$ & $<0.001$ \\
\hline $\begin{array}{l}\text { Do you feel concerned while } \\
\text { dealing with infected individuals? }\end{array}$ & $\begin{array}{l}22 \\
(4.60)\end{array}$ & $\begin{array}{l}51 \\
(10.67)\end{array}$ & $\begin{array}{l}112 \\
(23.4)\end{array}$ & $\begin{array}{l}233 \\
(48.74)\end{array}$ & $60(12.55)$ & .930 & .005 & .004 & .144 & .049 & $<0.001$ & .119 \\
\hline $\begin{array}{l}\text { Is the Health care system } \\
\text { adequately equipped? }\end{array}$ & $\begin{array}{l}36 \\
(7.53)\end{array}$ & $\begin{array}{l}127 \\
(26.6)\end{array}$ & $\begin{array}{l}96 \\
(20.08)\end{array}$ & $\begin{array}{l}194 \\
(40.59)\end{array}$ & $25(5.23)$ & .619 & $<0.001$ & .002 & $<0.001$ & .002 & $<0.001$ & $<0.001$ \\
\hline $\begin{array}{l}\text { Should there be a separate } \\
\text { room for CCHF confirmed patient? }\end{array}$ & $\begin{array}{l}14 \\
(2.93)\end{array}$ & $35(7.32)$ & $\begin{array}{l}68 \\
(14.23)\end{array}$ & $\begin{array}{l}218 \\
(45.61)\end{array}$ & $\begin{array}{l}143 \\
(24.48)\end{array}$ & .331 & .028 & $<0.001$ & $<0.001$ & .001 & $<0.001$ & $<0.001$ \\
\hline
\end{tabular}

Abbreviations: $S D$ strongly disagree, $D$ Disagree, $N$ Neutral, $A$ Agree, $S A$ Strongly agree.

Note: Bold values shown significant association 
Table 5 Perception of HCPs towards CCHF and differences in responses by demographic characteristics

\begin{tabular}{|c|c|c|c|c|c|c|c|c|c|c|c|c|}
\hline $\begin{array}{l}\text { Perception assessing } \\
\text { questions }\end{array}$ & SD & D & $\mathbf{N}$ & A & SA & Gender & Profession & Age & $\begin{array}{l}\text { Marital } \\
\text { status }\end{array}$ & $\begin{array}{l}\text { Experience } \\
\text { of Practice }\end{array}$ & Region & $\begin{array}{l}\text { Category } \\
\text { of practice }\end{array}$ \\
\hline $\begin{array}{l}\text { Will you follow standard } \\
\text { procedures to minimize the risk } \\
\text { of transmission of infection? }\end{array}$ & $\begin{array}{l}22 \\
(4.60)\end{array}$ & $\begin{array}{l}49 \\
(10.25)\end{array}$ & $\begin{array}{l}85 \\
(17.78)\end{array}$ & $\begin{array}{l}268 \\
(56.07)\end{array}$ & $\begin{array}{l}54 \\
(11.30)\end{array}$ & .273 & .001 & .053 & .069 & .045 & .511 & $<0.001$ \\
\hline $\begin{array}{l}\text { Do you have the quarantine } \\
\text { skills that you need to observe? }\end{array}$ & $\begin{array}{l}32 \\
(6.69)\end{array}$ & $\begin{array}{l}67 \\
(14.02)\end{array}$ & $\begin{array}{l}96 \\
(20.08)\end{array}$ & $\begin{array}{l}250 \\
(52.30)\end{array}$ & $\begin{array}{l}33 \\
(6.90)\end{array}$ & .048 & $<0.001$ & .051 & $<0.001$ & .010 & .169 & $<0.001$ \\
\hline $\begin{array}{l}\text { Use of preventive medicines } \\
\text { while dealing with CCHF } \\
\text { patients? }\end{array}$ & $\begin{array}{l}23 \\
(4.81)\end{array}$ & $\begin{array}{l}83 \\
(17.36)\end{array}$ & $\begin{array}{l}96 \\
(20.08)\end{array}$ & $\begin{array}{l}238 \\
(49.79)\end{array}$ & $\begin{array}{l}38 \\
(7.95)\end{array}$ & .259 & .009 & .002 & $<0.001$ & .002 & .642 & $<0.001$ \\
\hline $\begin{array}{l}\text { Do you have valuable sources of } \\
\text { information for CCHF? }\end{array}$ & $\begin{array}{l}20 \\
(4.18)\end{array}$ & $\begin{array}{l}75 \\
(15.69)\end{array}$ & $\begin{array}{l}92 \\
(19.25)\end{array}$ & $\begin{array}{l}258 \\
(53.97)\end{array}$ & $\begin{array}{l}33 \\
(6.90)\end{array}$ & .006 & .001 & $\begin{array}{l}< \\
0.001\end{array}$ & $<0.001$ & $<0.001$ & .452 & $<0.001$ \\
\hline $\begin{array}{l}\text { All healthcare professionals } \\
\text { should go for mandatory CCHF } \\
\text { testing during sporadic } \\
\text { outbreaks }\end{array}$ & $\begin{array}{l}11 \\
(2.30)\end{array}$ & $\begin{array}{l}36 \\
(7.53)\end{array}$ & $\begin{array}{l}250 \\
(52.3)\end{array}$ & $\begin{array}{l}155 \\
(32.43)\end{array}$ & $\begin{array}{l}26 \\
(5.44)\end{array}$ & .010 & $<0.001$ & .001 & .010 & $<0.001$ & $<0.001$ & $<0.001$ \\
\hline $\begin{array}{l}\text { Do pets increase the risk of } \\
\text { CCHF? }\end{array}$ & $\begin{array}{l}17 \\
(3.56)\end{array}$ & $\begin{array}{l}54 \\
(11.30)\end{array}$ & $\begin{array}{l}97 \\
(20.29)\end{array}$ & $\begin{array}{l}231 \\
(48.33)\end{array}$ & $\begin{array}{l}79 \\
(16.53)\end{array}$ & .222 & .110 & $\begin{array}{l}< \\
0.001\end{array}$ & $<0.001$ & $<0.001$ & .579 & $<0.001$ \\
\hline $\begin{array}{l}\text { Animal herders are at additional } \\
\text { risk of contracting disease }\end{array}$ & $\begin{array}{l}22 \\
(4.60)\end{array}$ & $\begin{array}{l}28 \\
(5.86)\end{array}$ & $\begin{array}{l}75 \\
(15.69)\end{array}$ & $\begin{array}{l}245 \\
(51.26)\end{array}$ & $\begin{array}{l}108 \\
(22.6)\end{array}$ & .539 & .005 & .001 & .004 & .021 & .582 & $<0.001$ \\
\hline
\end{tabular}

Abbreviations: $S D$ strongly disagree, $D$ Disagree, $N$ Neutral, $A$ Agree, $S A$ Strongly agree.

Note: Bold values shown significant association

relative higher education, physicians (especially senior), who could have motivated other HCPs toward better attitudes and safer practices, did not prove to have the best attitudes themselves.

Decades of research has shown that people have the capacity to voluntarily forget things, so to keep things in mind, reminders of information are needed [42]. Reading the authentic source of information is also essential to obtain the correct information so that the government and hospital policymakers should guide the recommended sources of information such as the WHO and the Center for Disease Control (CDC) guidelines. The Government of Pakistan and the higher authorities of the hospital should organize workshops and seminars periodically to keep hospital staff well informed about such neglected tropical diseases, especially before their peak seasons [36, 37]. HCPs should be ensured to follow the standard safety protocols, and hospital administration should ensure the availability of quarantine facilities for CCHF patients in hospitals. Further research is needed to evaluate the practices of HCPs concerning the following guidelines for preventive measures and safe disposal of syringes, medical devices and reporting and managing percutaneous exposures. Further research should also be conducted to assess the seroprevalence of CCHF in HCPs.

\section{Strength and limitations}

It is the first large-scale study in the endemic CCHF region of Pakistan, where there is not much literature available. The results of this study are useful for stakeholders and health policy officials to develop culturally appropriate interventions. The research identified differences in the necessary information and practice areas that could be addressed in future educational and learning activities. The findings also demonstrated that HCPs used less authentic sources of information; this should be addressed immediately as it ultimately affects knowledge and is reflected in attitudes and practices.

Research has some drawbacks, such as the use of a questionnaire to assess KAP, which can result in recall bias or social credibility bias. We recruit only HCPs working in emergencies of hospitals and infectious disease department staff, so the findings of the study can't be generalized for all categories of HCPs. CCHF is endemic in rural areas, while we have only collected data from hospitals in metropolitan areas, so caution should be taken when interpreting findings for rural settings.

\section{Conclusion}

Overall knowledge, attitude, and perceptions of high-risk HCPs reported in our study are lower than expectations. There is a serious need to arrange occupational safety and education courses for all HCPs working in endemic regions of Pakistan to encourage them to use only authentic academic sources of information. In the meantime, special attention is paid to nurses and less experienced HCPs to enhance their knowledge.

\section{Supplementary Information}

The online version contains supplementary material available at https://doi. org/10.1186/s12879-020-05714-z.

Additional file 1. 


\section{Abbreviations}

CCHF: Crimean Congo Haemorrhagic Fever; CCHFV: Crimean Congo Hemorrhagic Fever Virus; HCPs: Health Care Professionals; KAP: Knowledge, Attitudes, and Perceptions; WHO: World Health Organization

\section{Acknowledgements}

We would like to thank Dr. Furqan Hashmi, Akram Ahmed, and Salman Akram for their suggestions during the development of the questionnaire. We also acknowledge the voluntary participation of health workers in our research.

\section{Authors' contributions}

AA conceptualize the idea, AA, MS, MT, AH developed the questionnaire, AA, AHT collected data, A. A, MS, M.I.S analyze the data, A. A written the first draft of manuscript further reviewed by G. M, F. D and developed the final version of the manuscript. All authors approved the final version of the manuscript.

\section{Funding}

None.

\section{Availability of data and materials}

Data is available from the corresponding author on a reasonable request.

\section{Ethics approval and consent to participate}

Ethical approval was first obtained from the department of Pharmacy, Quaid I Azam University, Islamabad (Letter No: QAU/PharmacyDept/214), second ethical permission was obtained from the Ethical Review Board of Shaheed Zulfiqar Ali Bhutto Medical University (Letter No: F.1-1/2016/ERB/SZABMU/ 08/16) and the remaining hospitals allowed the research to be conducted based on university ethical approval letter.

Written informed consent was taken from all study participants.

\section{Consent for publication}

Not applicable.

\section{Competing interests}

We declare no competing interest.

\section{Author details}

${ }^{1}$ School of Pharmacy, Monash University, Jalan Lagoon Selatan, Bandar Sunway, 47500 Subang Jaya, Selangor, Malaysia. ${ }^{2}$ Department of Pharmacy, Quaid-i-Azam University, Islamabad 45320, Pakistan. ${ }^{3}$ PASTIC National Centre, Quaid-e-Azam University Campus, Islamabad, Pakistan.

\section{Received: 24 August 2020 Accepted: 16 December 2020} Published online: 07 January 2021

\section{References}

1. Mourya DT, Yadav PD, Gurav YK, Pardeshi PG, Shete AM, Jain R, Raval DD, Upadhyay KJ, Patil DY. Crimean Congo hemorrhagic fever serosurvey in humans for identifying high-risk populations and high-risk areas in the endemic state of Gujarat, India. BMC Infect Dis. 2019;19(1):104. https://doi. org/10.1186/s12879-019-3740-x

2. Kamboj, Aman and H. Pathak. "Crimean-Congo Hemorrhagic Fever: a comprehensive review." Vet World. 2013;6:812-7.

3. Logue J, Richter M, Johnson RF, Kuhn JH, Weaver W. Overview of Human Viral Hemorrhagic Fevers. In: Singh S., Kuhn J. (eds). Defense Against Biological Attacks. Cham: Springer. https://doi.org/10.1007/978-3030-03071-1_2.

4. Appannanavar SB, Mishra B. An update on Crimean Congo Hemorrhagic Fever. J Global Infect Dis. 2011;3(3):285.

5. Al-Abri SS, Al Abaidani I, Fazlalipour M, Mostafavi E, Leblebicioglu H, Pshenichnaya $\mathrm{N}$, et al. Current status of Crimean-Congo haemorrhagic fever in the World Health Organization eastern Mediterranean region: issues, challenges, and future directions. Int J Infect Dis. 2017:58:82-9.

6. Atif M, Saqib A, Ikram R, Sarwar MR, Scahill S. The reasons why Pakistan might be at high risk of Crimean Congo haemorrhagic fever epidemic; scoping review of the literature. Virol J. 2017;14(1):63.

7. WHO. World Health Organization Fact Sheet of Crimean-Congo haemorrhagic fever WHO Official Web Page. 2013 [Available from: https:// www.who.int/news-room/fact-sheets/detail/crimean-congo-haemorrhagicfever.

8. Greiner AL, Mamuchishvili N, Kakutia N, Stauffer K, Geleishvili M, Chitadze N, et al. Crimean-Congo hemorrhagic fever knowledge, attitudes, practices, risk factors, and Seroprevalence in rural Georgian villages with known transmission in 2014. PLoS One. 2016:11(6).

9. Rehman K, Bettani MAK, Veletzky L, Afridi S, Ramharter M. Outbreak of Crimean-Congo haemorrhagic fever with atypical clinical presentation in the Karak District of Khyber Pakhtunkhwa, Pakistan. Infect Dis Poverty. 2018; $7(1): 1-6$.

10. Koculu S, Oncul A, Onal O, Yesilbag Z, Uzun N. Evaluation of knowledge of the healthcare personnel working in Giresun province regarding CrimeanCongo hemorrhagic fever before and after educational training. J Vector Borne Dis. 2015;52(2):166.

11. Leblebicioglu H, Sunbul M, Memish ZA, Al-Tawfiq JA, Bodur H, Ozkul A, et al. Consensus report: preventive measures for Crimean-Congo hemorrhagic fever during Eid-al-Adha festival. Int J Infect Dis. 2015;38:9-15.

12. Mallhi TH, Khan $\mathrm{YH}$, Sarriff A, Khan AH. Crimean-Congo haemorrhagic fever virus and Eid-Ul-Adha festival in Pakistan. Lancet Infect Dis. 2016;16(12): 1332-3.

13. Ahmed A, Tahir MJ, Siddiqi AR, Dujaili J. Potential of Crimean-Congo Hemorrhagic fever outbreak during Eid-UI-Adha Islamic festival and COVID19 pandemic in Pakistan. J Med Virol. 2020.

14. NIHP. Advisory for prevention and control of Crimean Congo Hemorrhagic Fever (CCHF). Islamabad: NIH; 2019. [Available from: https://www.nih.org.pk/ wp-content/uploads/2019/07/Advisory-CCHF-July-2019.pdf.

15. Yousaf MZ, Ashfaq UA, Anjum KM, Fatima S. Crimean-Congo Hemorrhagic Fever (CCHF) in Pakistan: The "Bell" is Ringing Silently. Crit Rev Eukaryot Gene Expr. 2018;28(2)

16. Seasonal; awareness and alert letter (SAAL), for Epidemic-prone infectious diseases in Pakistan. National Institute of Health, Islamabad, Pakistan. 2020 [cited 13 July 2020]. Available from: https://www.nih.org.pk/newsletters/.

17. Zohaib A, Saqib M, Athar MA, Hussain MH, Sial A-u-R, Tayyab MH, et al. Crimean-Congo Hemorrhagic Fever Virus in Humans and Livestock, Pakistan, 2015-2017. Emerg Infect Dis. 2020;26(4):773.

18. Burney M, Ghafoor A, Saleen M, Webb P, Casals J. Nosocomial Outbrak of viral Hemorrhagic fever caused by Crimean Hemorrhagic fever-Congo virus in Pakistan, January 1976. Am J Trop Me Hyg. 1980;29(5):941-7.

19. Dawn. Surgeon dies of Congo fever: Dawn: https://www.dawn.com/ news/660423; 2011

20. News. Tests confirm Abbottabad doctor died of Congo fever: The News: http://thenews.compk/archive/print/262150-tests-confirm-abbottabaddoctor-died-of-congo-fever; 2010.

21. Bhatti MW. Surgeon from Bahawalpur hospital dies of CCHF at AKUH: The News; 2016. https://www.thenews.compk/print/138904-Surgeon-fromBahawalpur-hospital-dies-of-CCHF-at-AKUH.

22. Yadav PD, Patil DY, Shete AM, Kokate P, Goyal P, Jadhav S, et al. Nosocomial infection of CCHF among health care workers in Rajasthan, India. BMC Infect Dis. 2016:16(1):624

23. Rahnavardi M, Rajaeinejad M, Pourmalek F, Mardani M, Holakouie-Naieni K, Dowlatshahi S. Knowledge and attitude toward Crimean-Congo haemorrhagic fever in occupationally at-risk Iranian healthcare workers. J Hosp Infect. 2008;69(1):77-85.

24. Yildirmak T, Tulek N, Bulut C. Crimean-Congo haemorrhagic fever: transmission to visitors and healthcare workers. Infect. 2016;44(5):687-9.

25. World Health Organization. Advocacy, communication, and social mobilization for TB control: a guide to developing knowledge, attitude, and practice surveys. No. WHO/HTM/STB/2008.46. World Health Organization; 2008. https://apps.who.int/iris/handle/10665/43790.

26. Sheikh NS, Sheikh AS, Sheikh AA. Knowledge, attitude and practices regarding Crimean-Congo haemorrhagic fever among healthcare workers in Balochistan. J Ayub Med Coll Abbottabad. 2004;16(3).

27. Ahmed A, Tanveer M, Saqlain M, Khan GM. Knowledge, perception and attitude about Crimean Congo Hemorrhagic fever (CCHF) among medical and pharmacy students of Pakistan. BMC Public Health. 2018; 18(1):1333.

28. Salimi M, Afshar AA, Limoee M, Babakhani S, Chatrabgoun O, Hanafi-Bojd $A A$, et al. Knowledge, attitude and practice of healthcare workers concerning Crimean-Congo hemorrhagic fever in Western Iran. Asian Pac J Trop Biomed. 2016;6(6):546-50. 
29. Athar MN, Baqai HZ, Ahmad M, Khalid MA, Bashir N, Ahmad AM, et al. Crimean-Congo hemorrhagic fever outbreak in Rawalpindi, Pakistan February 2002. Am J Trop Med Hyg. 2003;69(3):284-7.

30. Mofleh JA, Asghar RJ, Kakar R, Zaidi S, Kazi B. Nosocomial outbreak of Crimean-Congo hemorrhagic fever in holy family hospital, Rawalpindi, Pakistan, 2010. J Public Health Epidemiol. 2013;5(4):173-7.

31. Raosoft I. Sample size calculator. Available from: ww raosoft com/ samplesize 2004.

32. WHO. Introduction to Crimean-Congo Haemorrhaigc Fever WHO Infectious diseases 2017 [Available from: https://www.who.int/publications/i/item/ introduction-to-crimean-congo-haemorrhaigc-fever.

33. WHO. WHO guideline development for CCHF clinical management and the WHO R\&D roadmap for CCHF and other actual aspects World Health Organization, 2018 [Available from: https://prepare.ersnet.org//rmedia/2018/ $\mathrm{pdf} / 515 . \mathrm{pdf}$.

34. Khan AM, Ansari J, Ishaq M, Muazam AR. Crimean Congo Hemorrhage Fever Cases in a Butcher Family at Hawailian, Abbottabad. J Saidu Med College. 2017;7(2):131-3.

35. Cagdas SNA, SAGLAM ZA, Toprak D, Sargn F, Mutlu HH. Knowledge attitude and practice survey regarding Crimean Congo Hemorrhagic fever among a sample of physicians in Turkey; 2012.

36. Yolcu S, Kader C, Kayipmaz AE, Ozbay S, Erbay A. Knowledge levels regarding crimean-Congo hemorrhagic fever among emergency healthcare workers in an endemic region. J Clin Med Res. 2014;6(3):197.

37. Suchitra J, Devi NL. Impact of education on knowledge, attitudes and practices among various categories of health care workers on nosocomial infections. Indian J Med Microbiol. 2007;25(3):181.

38. Manzoor I, Daud S, Hashmi NR, Sardar H, Babar MS, Rahman A, et al. Needle stick injuries in nurses at a tertiary health care facility. J Ayub Med College Abbottabad. 2010;22(3):174-8.

39. UI-Haq Z, Shah BH, Ardakani M, Khan SA, Muhammad S, Farooq S, et al. Health system preparedness in Pakistan for crisis management: a crosssectional evaluation study. East Mediterr Health J. 2019;25(8):553-61.

40. Ozer A, Miraloglu M, Ekerbicer HC, Cevik F, Aloglu N. Knowledge levels about Crimean-Congo hemorrhagic fever among midwifery and nursing students in Kahramanmaras, Turkey. Southeast Asian J Trop Med Public Health. 2010;41(1):77.

41. Sisman A. Epidemiologic features and risk factors of Crimean-Congo Hemorrhagic fever in Samsun Province, Turkey. J Epidemiol. 2013;23(2): 95-102.

42. Mahr JB, Csibra G. Witnessing, remembering, and testifying: why the past is special for human beings. Perspect Psychol Sci. 2020;15(2):428-43.

\section{Publisher's Note}

Springer Nature remains neutral with regard to jurisdictional claims in published maps and institutional affiliations.

Ready to submit your research? Choose BMC and benefit from:

- fast, convenient online submission

- thorough peer review by experienced researchers in your field

- rapid publication on acceptance

- support for research data, including large and complex data types

- gold Open Access which fosters wider collaboration and increased citations

- maximum visibility for your research: over $100 \mathrm{M}$ website views per year

At $\mathrm{BMC}$, research is always in progress.

Learn more biomedcentral.com/submissions 